\title{
Does television viewing make children obese? a review
}

\author{
Hasanuddin Nuru ${ }^{1,6}$, Noppawan Piaseu ${ }^{2}$, Sukri Palutturi ${ }^{3}, \operatorname{Rasdin}^{4}$, Zaenal $^{5}$, \\ Rini Mustamin ${ }^{5}$, Fardiana Mamang ${ }^{4}$
}

\author{
${ }^{1}$ Department of Nursing, Mahidol University, Bangkok, Thailand \\ ${ }^{2}$ Ramathibodi School of Nursing, Mahidol University, Bangkok, Thailand \\ ${ }^{3}$ Department of Public Health, Hasanuddin University, Makassar, Indonesia \\ ${ }^{4}$ Nursing and Midwifery Program, School of Nursing STIK-GIA Makassar, Indonesia \\ ${ }^{5}$ Faculty of Health Science, University of Islam, Makassar \\ ${ }^{6}$ Emergency Nursing Practitioner at DAYA Hospital, Makassar, Indonesia
}

Received: 08 August 2015

Revised: 05 September 2015

Accepted: 30 December 2015

\section{*Correspondence:}

Dr. Hasanuddin Nuru,

E-mail: hasanuddinmu@gmail.com

Copyright: (C) the author(s), publisher and licensee Medip Academy. This is an open-access article distributed under the terms of the Creative Commons Attribution Non-Commercial License, which permits unrestricted non-commercial use, distribution, and reproduction in any medium, provided the original work is properly cited.

\begin{abstract}
Watching television (TV) is an activity that very common and increasing in children and will lead to the adverse effects on health. This study aim to inform the readers, how TV viewing influences of weighs gain in the children. This data was collected from January 2003 to 2013 used Google scholar and PubMed databases with the published papers only. The articles were limited to English language and focus on the TV viewing, obesity and children as keywords. TV viewing has great influence to the consumption of high-fat foods whereas increase body mass index (BMI) eventually. Those who watch more frequently commercial TV will stimulates food intake and overconsumption, it's also promote sedentary behavior, less energy expenditure and have high risk to be obesity. TV viewing not just promote sedentary behavior or less energy expenditure but also stimulates food intake, overconsumption, influence food choice and eating occasion in front of the screen, whereas have significant correlation to the obesity in children.
\end{abstract}

Keywords: TV viewing, Obesity, Children

\section{INTRODUCTION}

Watching TV is an activity that very common in children. There is increasing concern that number of television watched by children will lead to the adverse effects on health. In the US for example there is 75 percent of children watched television for an average of approximately one hour and 20 minutes on typical day. ${ }^{1}$

While in China, children and adolescents who pay more attention to TV commercials are more likely to request, purchase, and consume snacks they see advertised on TV, paid attention to TV particularly commercial TV were more persuade to engage in the promoted snacking behavior. $^{2} \mathrm{TV}$ as a media has a disturbing potential to negatively affect many aspects of children's healthy development, including weight status, sexual initiation, aggressive feelings and beliefs, consumerism and social isolation. ${ }^{3}$

Nomerous studies asserted that advertising on children's television appears to be related to the prevalence of excess body weight among children. Furthermore, the content of the advertising appears to have a specific 
effect. $^{4}$ Food advertising intentionally targets children who are too young and immature to distinguish advertising puffery from truth, it's also encouraging children to consume high calorie, junk foods on a regular basis. Young children with limited cognitive abilities, often assume that the food products advertised on television are part of a healthy diet and maintain these misconceptions and develop unhealthy eating patterns at an early age. ${ }^{5}$

Another studied also stated that exposure to television food commercials enhanced high television viewers' preferences for branded foods and increased reported preferences for all food items. ${ }^{6}$

In a recent review of the literature examining the effect of television on children's consumption patterns, it's conclude that exposure to food advertisements significantly increases the likelihood that a child will select or request the advertised product, this is stronger evidence that TV has been proposed as contributed factor to the obesity. ${ }^{6-8}$

In contrast, others studies also regarded that contention TV viewing does not contribute to obesity because it is a sedentary activity. ${ }^{7}$ Additionally, Boyland, et al stated that children with greater previous exposure to commercials (high television viewers) seems to be more responsive to food promotion messages. ${ }^{6}$ Then Zimmerma, and Bell asserted that not all TV programs associated to the obesity particularly noncommercial television (educational television presented without inprogram commercials or videos or DVDs) had no statistically significant association with subsequent or concurrent obesity. $^{7}$

This literature explains us that TV viewing toward obesity is unclear topic so needs further study to bring us in the same perception. Therefore, this study aims to inform the readers, how does TV viewing associated to obesity in children.

\section{REVIEW METHODS}

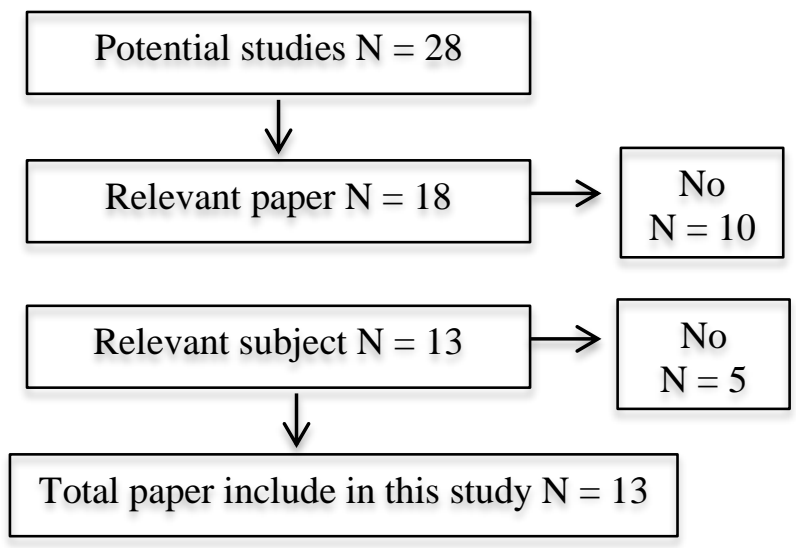

Figure 1: Flow diagram of study selection.

Data for this review were collected between January 2003 to 2013 used Google scholars and PubMed database with the published papers only. The articles were limited to English language and focus on the TV viewing, obesity and children as keywords.

\section{RESULTS}

Entire relating papers in this study were identified for review. These papers focus on TV viewing and obesity in children that was published in journals articles between 2003 till 2013 (within last 10 years), such elaborated in Table 1 below.

Table 1: Review of association between TV viewing and obesity in children.

\begin{tabular}{|c|c|c|c|c|c|}
\hline No & References & $\begin{array}{l}\text { Sample \& } \\
\text { population }\end{array}$ & $\begin{array}{l}\text { Stud } \\
\mathbf{y} \\
\text { Desig } \\
\mathbf{n}\end{array}$ & $\begin{array}{l}\text { Ig (Association } \\
\text { en TV viewing } \\
\text { besity) Yes/No }\end{array}$ & Comment \\
\hline 1. & $\begin{array}{l}\text { Sameer H. Al- } \\
\text { Ghamdi, } 2013\end{array}$ & $\begin{array}{l}\mathrm{N}=397 \text { age } 9-14 \\
\text { years old }\end{array}$ & $\begin{array}{l}\text { Case control } \\
\text { study }\end{array}$ & $\begin{array}{l}\mathrm{T} \\
\mathrm{f} \\
\mathrm{a} \\
\mathrm{p} \\
\mathrm{T} \\
\mathrm{a} \\
\mathrm{tl} \\
\mathrm{h} \\
\mathrm{il} \\
\mathrm{u} \\
\mathrm{s} \\
\mathrm{r}\end{array}$ & $\begin{array}{l}\text { TV watching represents an important risk } \\
\text { factor for obesity in children of school } \\
\text { age. It confirms that a substantial } \\
\text { percentage of children of school age view } \\
\text { TV for more than three hours on weekdays } \\
\text { and at weekends. Increase in a child's age, } \\
\text { the presence of more than one TV at } \\
\text { home, having their own TV, and an } \\
\text { increase in the number of hours of } \\
\text { watching TV over the weekend were } \\
\text { significantly associated with an increased } \\
\text { risk of childhood obesity. }\end{array}$ \\
\hline 2. & $\begin{array}{l}\text { Robert } \mathbf{J} \\
\text { Hancox, Barry } \mathbf{J}\end{array}$ & $\begin{array}{l}\mathrm{N}=1013 \text { age } 5-15 \\
\text { years old }\end{array}$ & $\begin{array}{l}\text { Cross } \\
\text { sectional }\end{array}$ & es & $\begin{array}{l}\text { Childhood and adolescent (age 5-15 } \\
\text { years) television viewing predicted a }\end{array}$ \\
\hline
\end{tabular}




\begin{tabular}{|c|c|c|c|c|c|}
\hline & $\begin{array}{l}\text { Milne, Richie } \\
\text { Poulton, } 2004\end{array}$ & & & & $\begin{array}{l}\text { higher body-mass index, lower } \mathrm{VO} 2 \text { max, } \\
\text { higher serum cholesterol, and increased } \\
\text { cigarette smoking at age } 26 \text { years. }\end{array}$ \\
\hline 3. & $\begin{array}{l}\text { Julio A Poterico } \\
\text { et, al. } 2008\end{array}$ & $\begin{array}{l}\mathrm{N}=21.712 \text { women } \\
\text { with age } 15-49 \\
\text { years old. }\end{array}$ & $\begin{array}{l}\text { Cross } \\
\text { sectional }\end{array}$ & Yes & $\begin{array}{l}\text { The mechanism by which television } \\
\text { viewing is associated with obesity is not } \\
\text { yet clearly established. It might be due to } \\
\text { lack of physical activity, and unhealthy } \\
\text { eating (consumption of high sugar- } \\
\text { sweetened beverages and processed foods) } \\
\text { while watching television. }\end{array}$ \\
\hline 4. & $\begin{array}{l}\text { Frederick J. } \\
\text { Zimmerma, and } \\
\text { Janice F. Bell, } \\
2010 .\end{array}$ & $\begin{array}{l}\mathrm{N}=1118 \text { with } 7-13 \\
\text { years old. }\end{array}$ & $\begin{array}{l}\text { Cross } \\
\text { sectional }\end{array}$ & No & $\begin{array}{l}\text { The evidence does not support the } \\
\text { contention that television viewing } \\
\text { contributes to obesity because it is a } \\
\text { sedentary activity. Television advertising, } \\
\text { rather than viewing per se, is associated } \\
\text { with obesity. }\end{array}$ \\
\hline 5. & $\begin{array}{l}\text { Donna M } \\
\text { Matheson, et, al. } \\
2004 .\end{array}$ & $\begin{array}{l}60 \text { students with } \\
7,8-9,6 \text { years old. }\end{array}$ & $\begin{array}{l}\text { Cross } \\
\text { sectional }\end{array}$ & Yes & $\begin{array}{l}\text { A significant proportion of children's } \\
\text { daily energy intake is consumed during } \\
\text { television viewing, and the consumption } \\
\text { of high-fat foods on weekends may be } \\
\text { associated with BMI in younger } \\
\text { children. }{ }^{12}\end{array}$ \\
\hline 6. & $\begin{array}{l}\text { Chrystalleni } \\
\text { Lazarou, et al. } \\
2009\end{array}$ & $\begin{array}{l}1140 \text { children } \\
(\text { mean age }= \\
10.7 \pm 0.98 \text { years })\end{array}$ & $\begin{array}{l}\text { Cross } \\
\text { sectional }\end{array}$ & Yes & $\begin{array}{l}\text { Sedentary behaviors such as TV watching } \\
\text { may be more important predictors of } \\
\text { children's various obesity indices than PA } \\
\text { behaviors. }\end{array}$ \\
\hline 7. & $\begin{array}{l}\text { I. Janssen, et al. } \\
2005\end{array}$ & $\begin{array}{l}137593 \text { youth } \\
\text { (10-16 years) }\end{array}$ & $\begin{array}{l}\text { Cross } \\
\text { sectional }\end{array}$ & Yes & $\begin{array}{l}\text { Television viewing as a leading factor } \\
\text { associated with adolescent obesity, the } \\
\text { mechanisms linking television viewing } \\
\text { with overweight and obesity in youth } \\
\text { include an increased caloric intake from } \\
\text { eating during viewing or from the effects } \\
\text { of food advertising, and reduced energy } \\
\text { expenditure from television viewing } \\
\text { displacing physical activity. }{ }^{14}\end{array}$ \\
\hline 8. & $\begin{array}{l}\text { Maria del } \\
\text { Carmen, et al. } \\
2009 .\end{array}$ & $\begin{array}{l}18784 \\
\text { adolescents with } \\
10-19 \text { years old. }\end{array}$ & $\begin{array}{l}\text { Cross } \\
\text { sectional }\end{array}$ & Yes & $\begin{array}{l}\text { Watching TV for long hours may lead to } \\
\text { an increased risk of obesity both through } \\
\text { reduction of energy use and changes in } \\
\text { diet. }\end{array}$ \\
\hline 9. & $\begin{array}{l}\text { Lori A. Francis, } \\
\text { Yoonna Lee, } \\
\text { and Leann L. } \\
\text { Birch, } 2003\end{array}$ & $\begin{array}{l}173 \text { non-Hispanic } \\
\text { white girls and } \\
\text { their parents aged } \\
5,7,9 \text { years old. }\end{array}$ & $\begin{array}{l}\text { Cross } \\
\text { sectional }\end{array}$ & Yes & $\begin{array}{l}\text { TVV was linked to weight gain through } \\
\text { snacking, with increased TVV relating to } \\
\text { more snacking in front of the TV and } \\
\text { more frequent snacking. These were } \\
\text { related to higher intakes of fat from ED } \\
\text { snack foods, which predicted girls } \\
\text { increase weight gain from age } 5 \text { to } 9 .{ }^{16}\end{array}$ \\
\hline 10. & $\begin{array}{l}\text { MH Proctor, } \\
2003 \text {. }\end{array}$ & $\begin{array}{l}106 \text { children were } \\
\text { enrolled during } \\
\text { preschool years } \\
\text { (mean age } 4.0 \mathrm{y} \text { ) } \\
\text { and followed into } \\
\text { early adolescence } \\
\text { (mean age } 11.1 \mathrm{y} \text { ) }\end{array}$ & $\begin{array}{l}\text { Longitudinal } \\
\text { study }\end{array}$ & Yes & $\begin{array}{l}\text { Children who watch more television and } \\
\text { play more video games may be less active } \\
\text { in general and may have less favorable } \\
\text { dietary habits. There seems to be some } \\
\text { interaction between these factors (diet, } \\
\text { activity, and television habits). } \\
\text { Television viewing alters the child's } \\
\text { intake of foods in ways that are not } \\
\text { adequately reflected by total energy intake } \\
\text { or percent of calories from fat. }^{17}\end{array}$ \\
\hline 11. & $\begin{array}{l}\text { Russel M. } \\
\text { Viner, and Tim } \\
\text { J. Cole, } 2005 .\end{array}$ & $\begin{array}{l}\text { Children who } \\
\text { watching TV up } \\
\text { to } 5 \mathrm{y}(\mathrm{N}=\end{array}$ & Cohort study & Yes & $\begin{array}{l}\text { TV viewing may increase BMI through } \\
\text { displacing physical activity or through } \\
\text { unhealthy food choices related to eating }\end{array}$ \\
\hline
\end{tabular}




\begin{tabular}{|c|c|c|c|c|c|}
\hline & & $\begin{array}{l}13,135), 10 \text { y }(\mathrm{N} \\
=14,875), \text { and } 30 \\
\mathrm{y} \\
(\mathrm{N}=11,261)\end{array}$ & & & while watching or to food advertising. ${ }^{18}$ \\
\hline 12. & $\begin{array}{l}\text { Froydis N Vik, } \\
\text { et al. } 2013\end{array}$ & $\begin{array}{l}7915 \text { children } \\
\text { (mean age: } 11.5 \\
\text { years) in eight } \\
\text { European } \\
\text { countries }\end{array}$ & Cohort study & Yes & $\begin{array}{l}\text { The odds of being overweight was lower } \\
\text { for children who reported to } \\
\text { never watch TV at lunch and dinner } \\
\text { compared to those who did. }{ }^{19}\end{array}$ \\
\hline 13. & $\begin{array}{l}\text { Ayako Sasaki, et } \\
\text { al. } 2010\end{array}$ & $\begin{array}{l}616 \text { preschool } \\
\text { children, who } \\
\text { were } 2 \text { to } 6 \text { years } \\
\text { of age }\end{array}$ & $\begin{array}{l}\text { Cross } \\
\text { sectional }\end{array}$ & No & $\begin{array}{l}\text { no positive association between TV } \\
\text { viewing and overweight status, possibly } \\
\text { owing to the influence of social } \\
\text { environment, low statistical power, or } \\
\text { misclassification. }\end{array}$ \\
\hline
\end{tabular}

$\mathrm{TV}$ viewing or media use is thought to be related to the weight gain in children because affect both energy intake and expenditure. This study has viewed thirteen papers that informed us about influence of TV viewing toward obesity in children, eleventh studies have conclude significant correlation between TV viewing and weight gain, while two studies stated no correlation. Based on this finding we can conclude that most of studies mentioned that $\mathrm{TV}$ viewing has positive relation to the obesity in children.

\section{DISCUSSION}

This study shows us that association between advertising and overweight among children may be mediated through more specific factors, such as generalized marketing activities (e.g. advertising to parents, promotions to children through the internet or at the point of sale) or through other non-specific socioeconomic factors (food pricing, food availability, cultural preferences) which influence consumption and lifestyle patterns but which are also reflected in the nature and degree of commercial advertising on children's television. ${ }^{21}$. TV viewing may not just promote sedentary behavior there is evidence that it's also stimulates food intake and overconsumption, specifically of snack foods. Children who eat their meals in front of the TV tend to consume more dietary fat. The number of hours of TV viewing by teenagers was significantly correlated with the number of unhealthy food items consumed per day, so could be concluded that relationship between TV viewing and childhood obesity appears not merely a matter of excessive sedentary activity but exposure to food adverts promotes more consumption calories. ${ }^{22}$

It's consistent with previous study that mentioned watching TV affect both energy intake and expenditure, it's requires no energy in excess of resting metabolic rates, and it may reduce the time spent in more energyexpensive activities. By watching TV is most of food heavily advertised and more likely to be consumed by children, not only that TV viewing will be a food references in the programs themselves. ${ }^{23}$ Another study support that reducing television, videotape, and video game use may be a promising, population-based approach to prevent childhood obesity. ${ }^{24}$

Additionally, television viewing also has been found to be associated with snacking behavior, and participants who spend more time watching television tend to follow an unhealthy eating pattern. The combination of those factors, less physical activity, increased sedentary behavior, less energy expenditure, and increased food and energy intake. ${ }^{25}$ There are two primary pathways that could explain the link between TV viewing and obesity. First, frequent TV viewing may lead to obesity through increased energy intake. For example, TV watching may trigger energy intake because hands are free and little else is happening. Excess intake may also occur outside of TV watching due to TV advertisements for foods high in sugar and fat. Second, frequent TV viewing may lead to obesity through decreased energy expenditure (i.e., increased sedentary living and/or decreased PA). Frequent TV watching could increase time spent sitting and could also displace exercise because of the lack of time. $^{26}$

Current study also stated that there are four proposed mechanisms underlying the relationship between television viewing and obesity in children: 1) the displacement a number of activities including homework and studying time, 2) reduction in resting metabolic rate which is leading to decrease in total energy expenditure and positive caloric balance 3 ) television content which has capacity to influence food choice and preference of children, and 4) between-meal snacking in front of the television (eating occasion in front of the screen). ${ }^{27}$

\section{Limitation of the study}

This study review only include relatively few, distributed studies across many years and mostly used cross sectional design, another limitation of this study is the study not explored the TV program such as commercial and noncommercial program in advance. Thus, it's hard to 
compare and determined whether TV viewing is independent factor for obesity in children.

\section{CONCLUSION}

TV viewing is something that needed by most childrens for gain refreshing mind or relax activity, but if we do more often will lead us to the adverse health consequencies such obesity. There four mechanisms underlying the relationship between television viewing and obesity in children first is displacement of activities, second decrease total energy expendicture, third influence food choice and preference of children, last eating occasion in front of the screen.

Funding: No funding sources

Conflict of interest: None declared

Ethical approval: The study was approved by the Institutional Ethics Committee

\section{REFERENCES}

1. Health MDo. Fast Forward to Better Health TV/Screen Time Obesity Report: Causes, Consequences and Remedies. In: Health Do, ed. 85 East Seventh Place St Paul, MN 55164: Minnesota Department of Health. 2010:1-32.

2. Parvanta SA, Brown JD, Du S, Zimmer CR, Zhao $X$, Zhai F. TV Use and Snacking Behaviors Among Children and Adolescents in China. J Adolesc Health. 2010;46(4):339-45.

3. Jat MRaKR. Effect of Electronic Media on Children. Indian Pediatrics. 2010;47:561-8.

4. Dibb TLaS. Evidence of a possible link between obesogenic food advertising and child overweight. The International Association for the Study of Obesity. 2005;6:203-8.

5. Termini RB, Roberto TA, Hostetter SG. Food Advertising and Childhood Obesity: A Call to Action for Proactive Solutions. Minnesota Journal of Law, Science \& Technology. 2011;12(2):619-51.

6. Boyland EJ, Harrold JA, Kirkham TC. Food Commercials Increase Preference for Energy-Dense Foods, Particularly in Children Who Watch More Television. American Academic of Pediatrics. 2011;128(1):93-100.

7. Zimmerman FJ, Bell JF. Associations of Television Content Type and Obesity in Children. American Journal of Public Health. 2010;100:334-40.

8. Haines J, Neumark-Sztainer D. Prevention of obesity and eating disorders: a consideration of shared risk factors. Health Education Research Theory \& Practice. 2006;21(6):770-82.

9. Al-Ghamdi SH. The association between watching television and obesity in children of school-age in Saudi Arabia. Journal of Family and Community Medicine. 2013;20(2):83-9.

10. Hancox RJ, Milne BJ, Poulton R. Association between child and adolescent television viewing and adult health: a longitudinal birth cohort study. Lancet. 2004;364:257-62.

11. Poterico JA, Bernabé-Ortiz A, Mola CLd, Miranda JJ. Association between television viewing and obesity in Peruvian women. Rev Saúde Pública. 2008:1-6.

12. Matheson DM, Killen JD, Wang Y, Varady A, Robinson TN. Children's food consumption during television viewing. Am J Clin Nutr. 2004;79:108894.

13. Lazarou C, Soteriades ES. Children's physical activity, TV watching and obesity in Cyprus: the CYKIDS study. European Journal of Public Health. 2009;20(1):70-7.

14. Janssen I, Katzmarzyk PT, Boyce WF. Comparison of overweight and obesity prevalence in school-aged youth from 34 countries and their relationships with physical activity and dietary patterns. obesity reviews. 2005;6:123-32.

15. Morales-Ruan MdC, Hernandez-Prado B, GomezAcosta LM, Shamah-Levy T, Cuevas-Nasu L. Obesity, overweight, screen time and physical activity in Mexican adolescents. Salud Publica Mex. 2009;51(4):S613-S620.

16. Francis LA, Lee Y, Birch LL. Parental Weight Status and Girls' Television Viewing, Snacking, and Body Mass Indexes. Obesity Research. 2003;11(1):143-51.

17. Proctor $\mathrm{M}$, Moore $\mathrm{L}$, Gao $\mathrm{D}$. Television viewing and change in body fat from preschool to early adolescence: The Framingham Children's Study. International Journal of Obesity. 2003;27:827-33.

18. Russell M. Viner M, Tim J. Cole P. Television viewing in early childhood predicts adult body mass index. J Pediatric. 2005;147:429-35.

19. Vik FN, Bjornara HB, Overby NC. Associations between eating meals, watching TV while eating meals and weight status among children, ages 10-12 years in eight European countries: the ENERGY cross-sectional study. International Journal of Behavioral Nutrition and Physical Activity. 2013;10(58):1-10.

20. Sasaki A, Yorifuji T, Iwase T, Komatsu H, Takao S, Doi H. Is There Any Association between TV Viewing and Obesity in Preschool Children in Japan? Acta Medica Okayama. 2010;64(2):137-42.

21. Lobstein T, Dibb AS. Evidence of a possible link between obesogenic food advertising and child overweight. Obesity reviews. 2005;6:203-8.

22. Halford JCG, Gillespie J, Brown V, Pontin EE, Dovey TM. Effect of television advertisements for foods on food consumption in children. Appetite. 2004;42:221-5.

23. Dietz WH, Gortmaker SL. Do we fatten our children at the Television set? Obesity and Television Viewing in Children and Adolescent. Pediatrics. 1985;75(5):807-12.

24. Robinson TN. Reducing Children's Television Viewing to Prevent Obesity a Randomized 
Controlled Trial. Journal American Medicine Association. 1999;282(16):1561-7.

25. Margeirsdottir HD, Larsen JR, Brunborg C, Sandvik L, Dahl-Jorgensen K. Strong Association Between Time Watching Television and Blood Glucose Control in Children and Adolescents With Type 1 Diabetes. Diabetes Care. 2007;30(6):1567-70.

26. Tucker LA, Tucker JM. Television Viewing and Obesity in 300 Women: Evaluation of the Pathways of Energy Intake and Physical Activity. Obesity. 2011;19(10):1960-6.
27. Borghese M, Chaput JP. Television Viewing Promoting Obesity in Children: Do We Really Know the Mechanism? Bioenergetics. 2013;2(1):12.

Cite this article as: Nuru $\mathrm{H}$, Piaseu N, Palutturi S, Rasdin, Zaenal, Mustamin R, et al. Does television viewing make children obese? a review. Int J Res Med Sci 2016;4:343-8. 